\title{
Comparative studies of versatile extracellular proteolytic activities of lactic acid bacteria and their potential for extracellular amino acid productions as feed supplements
}

Ye Heng Lim ${ }^{1}$, Hooi Ling Foo ${ }^{1,2^{*}}$ (D), Teck Chwen Loh ${ }^{3,4}$, Rosfarizan Mohamad ${ }^{1,2,5}$ and Norhani Abdullah ${ }^{1,4}$

\begin{abstract}
Background: Increasing understanding on the functions of amino acids (AA) has led to new commercial applications and expansion of the worldwide markets. However, the current technologies rely heavily on non-food grade microorganism and chemical synthesis for the production of AA. Several studies reported that lactic acid bacteria (LAB) have the capability of producing AA owing to their well-established proteolytic system and amino acid biosynthesis genes. Hence, the objectives of this study were to explore the extracellular proteolytic activity of $L A B$ isolated from various Malaysian fermented foods and their potential to produce AA extracellularly as feed supplements.

Results: All the studied LAB isolates were versatile extracellular protease producers, whereby extracellular protease activities were detected from acidic to alkaline $\mathrm{pH}(\mathrm{pH} 5, \mathrm{pH} 6.5, \mathrm{pH}$ 8) using qualitative and quantitative proteolytic assays. The highest proteolytic activity at pH $5(15.76 \mathrm{U} / \mathrm{mg})$ and pH $8(19.42 \mathrm{U} / \mathrm{mg})$ was achieved by Lactobacillus plantarum RG14, while Lactobacillus plantarum RS5 exhibited the highest proteolytic activity of $17.22 \mathrm{U} / \mathrm{mg}$ at pH 6.5. As for the results of AA production conducted in de Man, Rogosa and Sharpe medium and analysed by high pressure liquid chromatography system, all LAB isolates were capable of producing an array of AA. Generally, Pediococcus sp. showed greater ability for AA production as compared to Lactobacillus sp. Moreover, the studied LAB were able to produce a few major feed supplement AA such as methionine, lysine, threonine and tryptophan. P. pentosaceus TL-3 recorded the highest methionine and threonine productivity of $3.72 \mathrm{mg} / \mathrm{L} / \mathrm{h}$ and $5.58 \mathrm{mg} / \mathrm{L} / \mathrm{h}$ respectively. However, L. plantarum I-UL4 demonstrated a lysine productivity of $1.24 \mathrm{mg} / \mathrm{L} / \mathrm{h}$, while $P$. acidilactici TP-6 achieved up to $1.73 \mathrm{mg} / \mathrm{L} / \mathrm{h}$ of tryptophan productivity.
\end{abstract}

Conclusion: All the 17 studied LAB isolates possessed versatile extracellular proteolytic system and have vast capability of producing various amino acids including a few major feed supplement AA such as methionine, lysine, threonine and tryptophan. Despite AA production was strain dependent, the studied LAB isolates possessed vast potential and can be exploited further as a bio-agent or an alternative amino acids and bioactive peptide producers.

Keywords: Amino acid, Bio-agent, Extracellular proteolytic activity, Feed supplement, Lactic acid bacteria, Lactobacillus, Pediococcus

\footnotetext{
* Correspondence: hlfoo@upm.edu.my

${ }^{1}$ Institute of Bioscience, Universiti Putra Malaysia, 43400 UPM, Serdang, Selangor, Malaysia

${ }^{2}$ Department of Bioprocess Technology, Faculty of Biotechnology and Biomolecular Sciences, Universiti Putra Malaysia, 43400 UPM, Serdang, Selangor, Malaysia

Full list of author information is available at the end of the article
}

(c) The Author(s). 2019 Open Access This article is distributed under the terms of the Creative Commons Attribution 4.0 International License (http://creativecommons.org/licenses/by/4.0/), which permits unrestricted use, distribution, and reproduction in any medium, provided you give appropriate credit to the original author(s) and the source, provide a link to the Creative Commons license, and indicate if changes were made. The Creative Commons Public Domain Dedication waiver (http://creativecommons.org/publicdomain/zero/1.0/) applies to the data made available in this article, unless otherwise stated. 


\section{Background}

Amino acid (AA) are building blocks of proteins, which are one of the most essential components of life [1]. Increasing understanding on the functions and properties of amino acid had led to increasing commercial interest and diverse commercial applications. Over the past two decades, the development of AA industry was vibrant and revolved around AA for feed supplements, constituting $56 \%$ of the total AA market. Meanwhile, the remaining $44 \%$ were mainly used in food, pharmaceutical, agriculture and cosmetics sectors [2].

AA supplementation is commonly practised in livestock industry due to the limiting quantities of essential AA in the animal feeds, which may lead to growth impairment and poor productivity of livestock. Hence, AA supplementation is crucial to fulfil the limiting AA requirement of the animals and ensure proper function of the animals' biological system [3]. Besides, supplementation of AA allows the use of feed formula with low level of crude protein, which is economically advantageous and contributes greatly to relief crude protein deficiency [4]. The most commonly used AA in feed supplements include $L$-lysine, $D L$-methionine, $L$-threonine and $L$-tryptophan, due to their pronounced effects on livestock growth performance and meat quality [5-10]. Apart from improving the well-being and growth performance of livestock, supplementation of AA in the animals' diet could effectively improve nitrogen utilisation and minimise nitrogen excretion [11].

Generally, AA can be produced through three different methods, namely extraction, chemical synthesis and microbial methods. At present, microbial methods are conveniently used for the production of most AA due to its economic and ecological advantages [12]. The most commonly employed AA producer in the industry are genetically modified strains of Corynebacterium glutamicum and Escherichia coli [2]. However, industries may come to reluctant when using these microorganisms due to the pathogenicity and the non-food grade status [13]. Moreover, utilisation of genetically engineered bacteria for the production of AA had its share of controversies as the use of genetically modified C. glutamicum for the production of AA has been linked to over thousand cases of a deadly syndrome, known as eosinophila myalgia syndrome (EMS). This has urged for the search of food grade microorganisms as an alternative AA producer.

Lactic acid bacteria (LAB) appear to be an excellent alternative candidate for AA production, due to their non-pathogenic nature and reputation as "Generally Recognised as Safe (GRAS)" bacteria [14]. LAB are one of the most commonly employed probiotics [15-17], attributing to their important role in improving the gastrointestinal health $[18,19]$ of the host by producing antimicrobial compounds [19-21] and reducing harmful microorganisms in the intestine [22]. Several reports suggested that LAB possess a well-established proteolytic system, which may contribute to the hydrolysis of complex protein to release free AA [23-26]. Additionally, the presence of active AA biosynthesis pathway and the relevant genes responsible for AA production have been reported for LAB [27, 28].

Despite extensive reports on proteolytic activity of $\mathrm{LAB}$, the documentation on application of $\mathrm{LAB}$ for the production of AA are very limited. Hence, the objectives of this study were to explore the extracellular proteolytic activity of LAB isolated from various Malaysian fermented foods and to evaluate their ability to produce AA particularly extracellularly for feed supplements.

\section{Methods \\ Microorganism and maintenance}

Seventeen LAB isolates [9 Lactobacillus plantarum: TL-1, TL-2, TP-2, TP-5 (isolated from tempeh-fermented soybean cake), I-UL4 (isolated from tapai ubi-fermented cassava), RI 11, RG 11, RG 14, RS 5 (isolated from ikan rebus-steam fish); 6 Pediococcus pentosaceus: B12m9 (isolated from budu-fermented fish sauce), TB-1, TL-3, TP-3, TP-4, TP-8 (isolated from tempeh-fermented soybean cake); 2 Pediococcus acidilactici: TB-2, TP-6 (isolated from tempeh-fermented soybean cake)] that previously isolated from Malaysian fermented foods were obtained from the Laboratory of Industrial Biotechnology, Department of Bioprocess Technology, Faculty of Biotechnology and Biomolecular Sciences, Universiti Putra Malaysia [29-31]. The LAB cultures were maintained and revived as described by Foo et al. [32].

\section{Determination of proteolytic activity Preparation of extracellular enzyme}

The preparation of extracellular enzymes were performed according to the method of Thung [31] with slight modification, where a smaller inoculum size of $1 \%$ $(v / v)$ was used in this study. In brief, the active LAB culture was washed once with sterile $0.85 \%(w / v) \mathrm{NaCl}$ (Merck, Germany) solution and adjusted to $10^{9} \mathrm{CFU} / \mathrm{mL}$ to be used as inoculum. A volume of $1 \%(v / v)$ of the adjusted LAB culture was inoculated into $10 \mathrm{~mL}$ de Man, Rogosa and Sharpe (MRS) medium (Merck, Germany) and incubated at $30^{\circ} \mathrm{C}$ for $10 \mathrm{~h}$, followed by centrifugation at $10,000 \times g$ for $15 \mathrm{~min}$ to separate the biomass from supernatant. The supernatant was then collected and filtered through a $0.2-\mu \mathrm{m}$ cellulose acetate membrane (Sartorius Stedim, Germany) to obtain cell-free-supernatant (CFS), which was used as extracellular enzyme for the determination of extracellular proteolytic activity. 


\section{Qualitative determination of proteolytic activity}

The proteolytic activity of the LAB isolate was detected qualitatively by using skim milk agar hydrolysis method [31] with minor modification, where log phase $(10 \mathrm{~h})$ culture was used in the assay. A loopful of $10 \mathrm{~h} \mathrm{LAB}$ culture with a cell population of $10^{9} \mathrm{CFU} / \mathrm{mL}$ was streaked on skim milk agar containing $1 \%(w / v)$ skim milk (Merck, Germany) and incubated at $30^{\circ} \mathrm{C}$ for $48 \mathrm{~h}$. Proteolytic activity was indicated by the occurrence of clear hydrolysis zone. All analyses were performed in triplicates.

\section{Effect of $\mathrm{pH}$ on extracellular proteolytic activity}

Skim milk agar well diffusion (SMAWD) assay was used to determine the active $\mathrm{pH}$ range of the extracellular proteases produced by the LAB isolates. Three different $\mathrm{pH}$ conditions provided by $0.1 \mathrm{~mol} / \mathrm{L}$ sodium acetate buffer ( $\mathrm{pH} 5.0), 0.1 \mathrm{~mol} / \mathrm{L}$ sodium phosphate buffer $(\mathrm{pH}$ 6.5) and $0.1 \mathrm{~mol} / \mathrm{L}$ Tris- $\mathrm{HCl}$ buffer $(\mathrm{pH} 8.0)$ were used in the assay [31]. The CFS was mixed with the respective buffer at 1:1 ratio. A volume of $20 \mu \mathrm{L}$ of the buffered CFS was then inoculated into the pre-punched well on skim milk agar and incubated for $48 \mathrm{~h}$ at $30{ }^{\circ} \mathrm{C}$, followed by observation for clear hydrolysis zone. Buffer of respective $\mathrm{pH}$ without $\mathrm{CFS}$ was used as control. All analyses were performed in triplicates.

\section{Quantification of extracellular proteolytic activity}

The extracellular protease activity was quantified under 3 different $\mathrm{pH}$ conditions as described by Thung [31] with minor modification. In brief, $0.25 \mathrm{~mL}$ of CFS was added to $0.5 \mathrm{~mL}$ of buffer containing $0.5 \%(w / v)$ sulphanilamide azocasein (Sigma Aldrich, USA) and incubated at $37^{\circ} \mathrm{C}$ for $30 \mathrm{~min}$. Next, $0.75 \mathrm{~mL}$ of $10 \%(w / v)$ trichloroacetic acid (Merck, Germany) was added and incubated at room temperature for $30 \mathrm{~min}$ to terminate the reaction. The precipitate was removed by centrifugation at $12,000 \times g$ for $10 \mathrm{~min}$. A volume of $0.6 \mathrm{~mL}$ of the supernatant was mixed with $0.6 \mathrm{~mL}$ of $1 \mathrm{~mol} / \mathrm{L} \mathrm{NaOH}$ (Merck, Germany) and incubated for $15 \mathrm{~min}$ at room temperature prior to measuring its absorbance at 450 $\mathrm{nm}$. The control of the assay was prepared by substituting the CFS and substrate with buffer respectively. One unit $(\mathrm{U} / \mathrm{mg})$ of specific protease activity was defined as the amount of enzyme capable of hydrolysing sulphanilamide-azocasein to produce 0.001 change in absorbance per minute of incubation time per $\mathrm{mg}$ of protein under the assay condition. All analyses were performed in triplicates.

\section{Protein content determination}

Protein content of the CFS was determined by using Bradford method [33], whereby bovine serum albumin (Sigma Aldrich, USA) was used as reference. In brief,
$0.5 \mathrm{~mL}$ of appropriately diluted CFS was mixed with 0.5 $\mathrm{mL}$ of Bradford reagent (Sigma Aldrich, USA) and incubated for $5 \mathrm{~min}$ at $4{ }^{\circ} \mathrm{C}$. The absorbance was measured at $595 \mathrm{~nm}$ using a Varian Cary 50 spectrophotometer (Agilent Technologies, USA) and the protein content was quantified based on the standard curve of bovine serum albumin. All analyses were performed in triplicates.

\section{Production of amino acids by $L A B$ isolates}

The production of AA was conducted as described by Norfarina et al. [34] with modifications. Briefly, the active LAB culture was washed once with $0.85 \%(w / v)$ $\mathrm{NaCl}$ solution and adjusted to a cell population of $10^{9}$ $\mathrm{CFU} / \mathrm{mL}$. A volume of $10 \%(v / v)$ of the adjusted culture was then inoculated into MRS medium and incubated at $30^{\circ} \mathrm{C}$ for $24 \mathrm{~h}$. Samples were collected at every $2 \mathrm{~h}$ intervals and the CFS was used for the determination of AA production profile. The MRS medium without inoculum was served as control.

\section{Determination of amino acid production profile}

The AA production profile of CFS was analysed as described by Henderson et al. [35] by using Agilent 1100 high performance liquid chromatograph (HPLC) (Agilent Technologies, USA). Derivatisation of AA was performed by using o-phthalaldehyde (OPA) and 9- fluorenylmethyl chloroformate (FMOC). The derivatised AA were separated on a Zorbax Eclipse Plus C18 reverse phase column (4.6 $\mathrm{mm} \times 150 \mathrm{~mm}, 3.5 \mu \mathrm{m})$ (Agilent Technologies, USA). The bound AA were eluted with $40 \mathrm{mmol} / \mathrm{L}$ sodium dihydrogen phosphate monohydrate $\left(\mathrm{NaH}_{2} \mathrm{PO}_{4} \cdot \mathrm{H}_{2} \mathrm{O}\right)$ adjusted to $\mathrm{pH} 7.8$ and a methanol-acetonitrile-deionised water mixture (9:9:2) at a flow rate of $2 \mathrm{~mL} / \mathrm{min}$. The OPA, FMOC and $\mathrm{NaH}_{2} \mathrm{PO}_{4} \cdot \mathrm{H}_{2} \mathrm{O}$ were analytical grade while the methanol and acetonitrile were HPLC grade that purchased from Merck. The eluted derivatised AA were detected by a fluorescence detector (Agilent Technologies, USA) at the excitation/emission wavelengths of 340/450 $\mathrm{nm}$ for primary AA and $266 / 305 \mathrm{~nm}$ for secondary AA. The AA concentration was quantified by referring to the calibration curve constructed by using AA standard (Sigma Aldrich, USA). The production of AA was calculated by deducting the highest concentration of each AA with their respective initial concentration. All analyses were performed in triplicates.

\section{Statistical analysis}

The results were analysed by one-way analysis of variance (ANOVA) using Statistical Analysis System (SAS 9.1, USA). Duncan's Multiple Range Test System was used to compare the significant difference between the mean at $P<0.05$. 


\section{Results \& discussion}

\section{Qualitative determination of extracellular proteolytic} activity

The proteolytic activity of LAB had been studied extensively due to their industrial importance [36] and essential role in ensuring the survival of the bacteria [37, 38]. In the present study, the ability of the 17 LAB isolated from Malaysian fermented foods to produce and secrete extracellular proteolytic enzymes was determined qualitatively by using skim milk agar hydrolysis assay. Results obtained in this study revealed that all the 17 studied $\mathrm{LAB}$ isolates were capable to produce clear hydrolysis zone on skim milk agar as illustrated in Fig. 1. This inferred that all the 17 tested LAB isolates were capable to produce and secrete extracellular proteolytic enzymes, which is responsible to hydrolyse whitish opaque colour casein molecules into colourless peptide fragments, thereby producing clear zone around the culture. Pailin et al. [39] reported similar finding, where all studied $\mathrm{LAB}$ isolates demonstrated ability to form clear zone on skim milk. Likewise, majority of the LAB isolated from Algerian goat's milk [40] and Egyptian Ras cheese [41] have demonstrated the ability to produce clear hydrolysis zone on skim milk agar. This implied that majority of LAB possessed extracellular proteolytic activity.

\section{Effects of $\mathrm{pH}$ on extracellular proteolytic activity}

The effects of $\mathrm{pH}$ on extracellular proteolytic activity of the LAB isolates were investigated by using SMAWD assay in three different $\mathrm{pH}$ conditions that resembled acidic ( $\mathrm{pH} 5)$, near neutral ( $\mathrm{pH} 6.5)$ and alkaline $(\mathrm{pH} 8)$ conditions. Generally, proteolytic enzymes can be categorised into three distinct groups, namely acidic, neutral and alkaline proteases based on their active $\mathrm{pH}$ range [42]. Results obtained in the current study demonstrated that the CFS of the 17 LAB isolates have the capability to produce clear zone of hydrolysis under three different
$\mathrm{pH}$ conditions, where occurrence of halo was observed around the well containing CFS adjusted to different $\mathrm{pH}$ conditions. The diameter of clear hydrolysis zone produced by CFS of the $17 \mathrm{LAB}$ isolates under 3 different $\mathrm{pH}$ conditions are summarised in Table 1. Development of clear hydrolysis zone by CFS of the LAB suggested that the proteolytic enzymes produced by the isolates were secreted and active extracellularly. This is in agreement with the findings reported by Beganovic et al. [43], where formation of clear hydrolysis zone around the skim milk agar well inoculated with actively growing $\mathrm{LAB}$ cell was observed, indicating that $\mathrm{LAB}$ were capable to produce and secrete extracellular proteolytic enzymes. The presence of extracellular proteolytic activity in Lactobacillus acidophilus, Bifidobacterium sp., L. casei, Streptococcus thermophilus, and Pediococcus acidilactici was also well documented [44, 45]. However, the occurrence of hydrolysis zone under different $\mathrm{pH}$ conditions (Table 1) indicated that the extracellular proteases produced by the studied $\mathrm{LAB}$ isolates were active from acidic to alkaline $\mathrm{pH}$, and hence implied that they were versatile producer for extracellular proteolytic enzymes. Similar findings were reported by Addi and Guessas [46], where proteolytic activity was detected in CFS of Lactococcus sp. over a broad $\mathrm{pH}$ conditions ranging from $\mathrm{pH} 5.5$ to $\mathrm{pH} 8$ with the highest proteolytic activity detected at near neutral condition ( $\mathrm{pH}$ 7.2).

The extracellular proteolytic activity of the LAB isolates were also determined semi-quantitatively by measuring the diameter of clear hydrolysis zone produced by the $\mathrm{pH}$ adjusted CFS of the LAB isolates. A larger clear hydrolysis zone indicated the occurrence of higher proteolytic activity. Results obtained in current study showed that all the $17 \mathrm{LAB}$ isolates demonstrated significantly higher $(P<0.05)$ extracellular proteolytic activity under acidic condition, except $L$. plantarum TP-2, which revealed no significant difference $(P>0.05)$
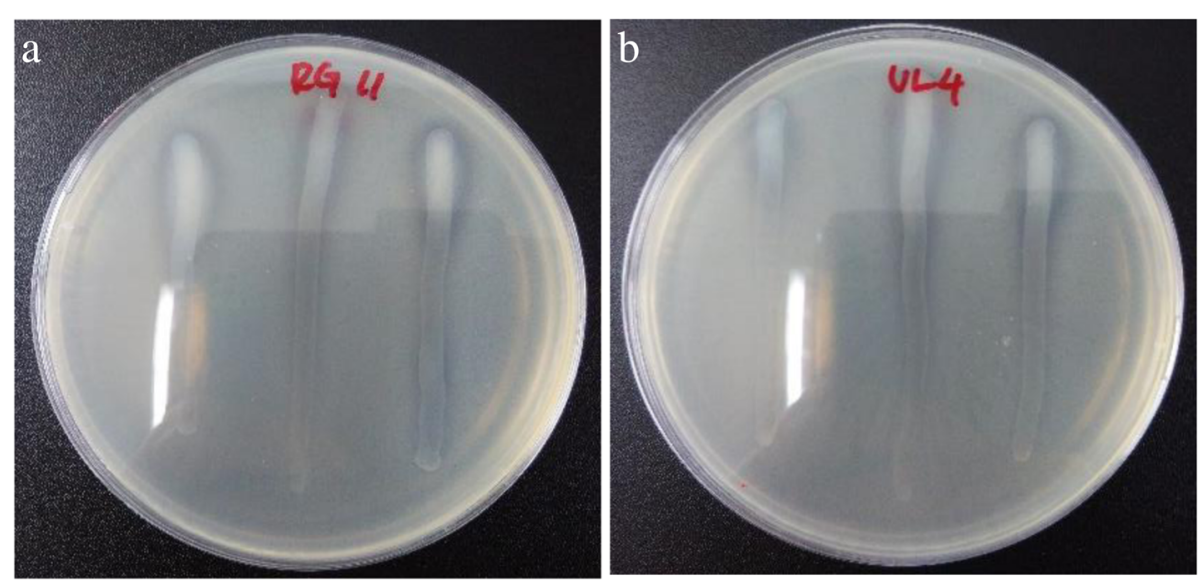

Fig. 1 Representative of hydrolysis zone formation obtained in skim milk agar hydrolysis assay. a L. plantarum RG 11, (b) L. plantarum I-UL4 
Table 1 Diameter of hydrolysis zone formed by CFS of LAB isolates in SMAWD assay

\begin{tabular}{|c|c|c|c|c|c|c|}
\hline Isolates & $\mathrm{pH} 5^{*}$ & Level** & $\mathrm{pH} 6.5$ & Level & $\mathrm{pH} 8$ & Level \\
\hline P. pentosaceus B12m9 & $1.17 \pm 0.03^{\mathrm{Aa}}$ & +++ & $1.00 \pm 0.00^{\mathrm{ABCb}}$ & ++ & $0.90 \pm 0.00^{C D C}$ & + \\
\hline P. pentosaceus TB-1 & $1.20 \pm 0.00^{\mathrm{Aa}}$ & +++ & $0.87 \pm 0.03^{\mathrm{Eb}}$ & + & $0.90 \pm 0.00^{\mathrm{CDb}}$ & + \\
\hline P. pentosaceus TL-3 & $1.17 \pm 0.03^{\mathrm{Aa}}$ & +++ & $0.97 \pm 0.03^{\mathrm{BCDb}}$ & + & $0.97 \pm 0.03^{\mathrm{BCb}}$ & + \\
\hline P. pentosaceus TP-3 & $1.13 \pm 0.03^{\mathrm{ABa}}$ & +++ & $0.90 \pm 0.00^{\mathrm{DEb}}$ & + & $0.93 \pm 0.03^{B C b}$ & + \\
\hline P. pentosaceus TP-4 & $1.13 \pm 0.03^{\mathrm{ABa}}$ & +++ & $0.93 \pm 0.03^{\mathrm{CDEb}}$ & + & $0.90 \pm 0.00^{\mathrm{CDb}}$ & + \\
\hline P. pentosaceus TP-8 & $1.13 \pm 0.03^{\mathrm{ABa}}$ & +++ & $0.93 \pm 0.03^{\mathrm{CDEb}}$ & + & $0.90 \pm 0.00^{\mathrm{CDb}}$ & + \\
\hline P. acidilactici TB-2 & $1.13 \pm 0.03^{\mathrm{ABa}}$ & +++ & $0.93 \pm 0.03^{\mathrm{CDEb}}$ & + & $0.83 \pm 0.03^{\mathrm{DEb}}$ & + \\
\hline P. acidilactici TP-6 & $1.10 \pm 0.00^{\mathrm{ABa}}$ & +++ & $0.90 \pm 0.00^{\mathrm{DEb}}$ & + & $0.80 \pm 0.00^{\mathrm{EC}}$ & + \\
\hline L. plantarum TL-1 & $1.13 \pm 0.03^{\mathrm{ABa}}$ & +++ & $0.93 \pm 0.03^{\mathrm{CDEb}}$ & + & $0.90 \pm 0.00^{\mathrm{CDb}}$ & + \\
\hline L. plantarum TL-2 & $1.20 \pm 0.00^{\mathrm{Aa}}$ & +++ & $1.00 \pm 0.00^{\mathrm{ABCb}}$ & ++ & $1.00 \pm 0.00^{\mathrm{Bb}}$ & ++ \\
\hline L. plantarum TP-2 & $1.13 \pm 0.03^{\mathrm{ABa}}$ & +++ & $1.03 \pm 0.03^{\mathrm{ABa}}$ & ++ & $1.07 \pm 0.03^{\mathrm{Aa}}$ & ++ \\
\hline L. plantarum TP-5 & $1.20 \pm 0.00^{\mathrm{Aa}}$ & +++ & $1.07 \pm 0.03^{\mathrm{Ab}}$ & ++ & $1.10 \pm 0.00^{\mathrm{Ab}}$ & +++ \\
\hline L. plantarum Rl11 & $1.13 \pm 0.03^{\mathrm{ABa}}$ & +++ & $1.00 \pm 0.00^{\mathrm{ABCb}}$ & ++ & $0.90 \pm 0.00^{\mathrm{CD} v}$ & + \\
\hline L. plantarum RG11 & $1.07 \pm 0.03^{\mathrm{Ba}}$ & ++ & $0.93 \pm 0.03^{\mathrm{CDEb}}$ & + & $0.93 \pm 0.03^{\mathrm{BCb}}$ & + \\
\hline L. plantarum RG14 & $1.17 \pm 0.03^{\mathrm{Aa}}$ & +++ & $0.97 \pm 0.03^{\mathrm{BCDb}}$ & + & $0.93 \pm 0.03^{\mathrm{BCb}}$ & + \\
\hline L. plantarum RS5 & $1.07 \pm 0.03^{\mathrm{Ba}}$ & ++ & $0.93 \pm 0.03^{\mathrm{CDEb}}$ & + & $0.93 \pm 0.03^{B C b}$ & + \\
\hline L. plantarum I-UL4 & $1.13 \pm 0.03^{\mathrm{ABa}}$ & +++ & $0.97 \pm 0.03^{\mathrm{BCDb}}$ & + & $0.93 \pm 0.03^{\mathrm{BCb}}$ & + \\
\hline
\end{tabular}

*Values are mean \pm standard error of the mean (SEM), $n=3$. Mean \pm SEM within the same column that share a similar capital letter superscript (A-E) are not significantly different $(P>0.05)$ while means within the same row that bear a common small letter superscript $(a-c)$ indicate no significant difference $(P>0.05)$ ${ }^{* *}$ The level of proteolytic activity was assigned based on the diameter of clear hydrolysis zone such that: ' + ' indicates $<1.0 \mathrm{~cm}$; ' ++ ' indicates $\geq 1.0 \mathrm{~cm}$ but $<1.10$ $\mathrm{cm}$ whereas ' +++ ' indicates $\geq 1.10 \mathrm{~cm}$

between the extracellular proteolytic activities in 3 different $\mathrm{pH}$ conditions (Table 1). Similar findings were reported by Rollán et al. [47, 48], where the extracellular proteases of Leuconostoc oenos showed higher proteolytic activity at acidic $\mathrm{pH}$ condition. In addition, de Giori et al. [49] also demonstrated that the proteolysis of Lactococci and Lactobacillus casei occurred optimally between $\mathrm{pH}$ 4.8-5.6. The higher extracellular proteolytic activity at acidic $\mathrm{pH}$ condition could be attributed to the acidophilic nature of LAB [50]. Extracellular enzymes of acidophilic microorganisms are often optimally active at low $\mathrm{pH}$ [51]. Nevertheless, the extracellular proteolytic activity for most of the LAB isolates at $\mathrm{pH} 6.5$ and $\mathrm{pH} 8$ were not significantly different $(P>0.05)$, except for $P$. pentosaceus B12m9, P. acidilactici TP-6 and L. plantarum RI11, which demonstrated significantly higher $(P<0.05)$ extracellular proteolytic activity at pH 6.5.

Among the 17 tested LAB isolates, the highest extracellular proteolytic activity at $\mathrm{pH} 5$ was detected in $P$. pentosaceus $\mathrm{TB}-1, L$. plantarum $\mathrm{TL}-2$ and $L$. plantarum TP-5, where the largest clear hydrolysis zone with a diameter of $1.2 \mathrm{~cm}$ was observed. However, they were not significantly different $(P>0.05)$ as compared to other LAB isolates, except for L. plantarum RG11 and L. plantarum RS5. In comparison, the highest extracellular proteolytic activity at pH6.5 was achieved by $L$. plantarum TP-5. Nevertheless, it was not significantly different $(P>0.05)$ as compared to $P$. pentosaceus
B12m9, L. plantarum TP-2 and L. plantarum RI11. On the other hand, the highest alkaline protease activity was recorded by $L$. plantarum TP-5, followed by $L$. plantarum TP-2. Generally, L. plantarum TP-5 exhibited the highest extracellular proteolytic activity, where the largest clear hydrolysis zone was observed under all the 3 $\mathrm{pH}$ conditions, followed by L. plantarum TL-2 and $L$. plantarum TP-2.

\section{Quantification of extracellular proteolytic activity}

The extracellular proteolytic activity of the $17 \mathrm{LAB}$ isolates was further quantified by using sulphanilamide-azocasein as substrate under three different $\mathrm{pH}$ conditions. Results that obtained in the quantitative assay (Fig. 2) were in agreement with the results obtained in SMAWD assay, whereby all the 17 tested LAB isolates exhibited extracellular proteolytic activity in three different $\mathrm{pH}$ conditions $(\mathrm{pH} 5, \mathrm{pH} 6.5$ and $\mathrm{pH}$ 8 respectively). In general, Lactobacillus sp. demonstrated comparatively higher extracellular proteolytic activity as compared to Pediococcus sp. The extracellular proteolytic activity of Lactobacillus sp. was between $7 \mathrm{U} / \mathrm{mg}$ to $19 \mathrm{U} / \mathrm{mg}$, whereas the extracellular proteolytic activity of Pediococcus sp. were between $6 \mathrm{U} / \mathrm{mg}$ to $11 \mathrm{U} / \mathrm{mg}$, indicating the highest extracellular proteolytic activity of Pediococcus sp. was approximately half of those recorded by Lactobacillus sp. A study conducted by Pailin et al. [39] also showed that Lactobacillus sp. exhibited comparatively higher extracellular proteolytic activity as compared to other tested LAB species. 


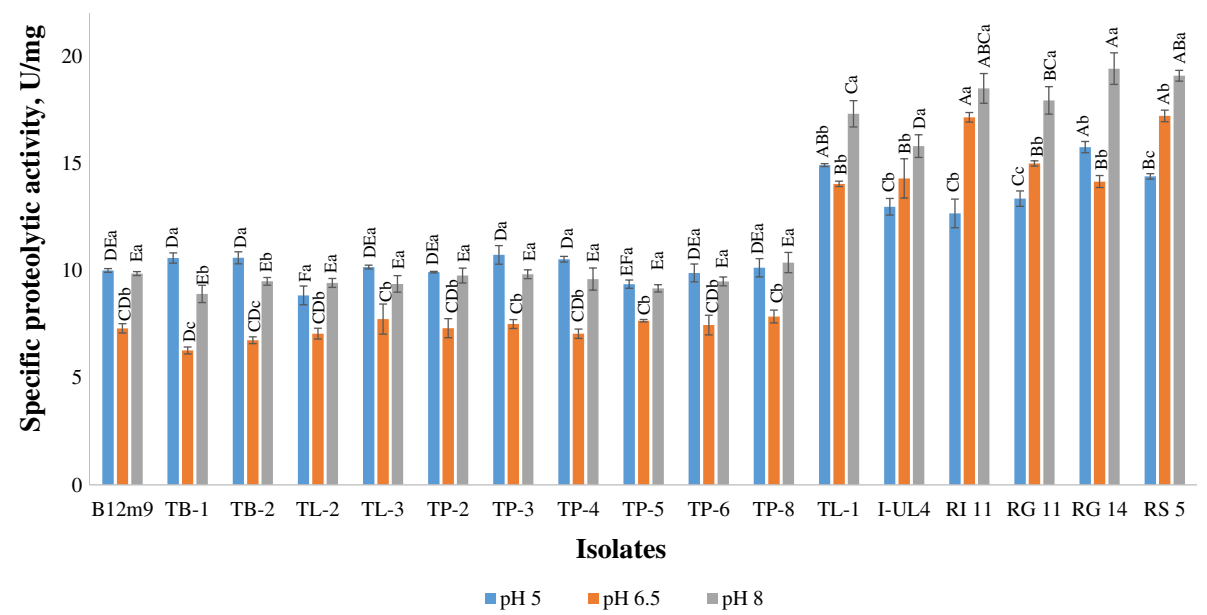

Fig. 2 Extracellular proteolytic activity of $L A B$ isolates at pH 5, pH 6.5 and $\mathrm{pH}$ 8. Values are mean \pm standard error mean (SEM), $n=3$. Vertical bars represent SEM. Values bearing different capital letter alphabets $(A-F)$ among bacteria isolates are significant different $(P<0.05)$ while values sharing different small letter alphabet $(\mathrm{a}-\mathrm{C})$ among various $\mathrm{pH}$ are significant different $(P<0.05)$

This could be attributed to the disruption of amino acid synthesis pathway in Lactobacillus sp., which is compensated with pronounced proteolytic activity [52].

Each LAB isolate produced different strength of extracellular proteolytic activity under different $\mathrm{pH}$ conditions, indicating that the proteolytic activity of LAB was strain dependent. For instances, 2 of the tested LAB isolates ( $P$. pentosaceus TB-1 \& P. acidilactici TB-2) demonstrated significantly higher $(P<0.05)$ extracellular proteolytic activity at $\mathrm{pH} 5$, which is in agreement with de Giori et al. [49] who has reported that higher proteolytic activity was detected in LAB under acidic condition and a marked reduction in proteolytic activity of $\mathrm{LAB}$ was detected when the $\mathrm{pH}$ was near neutral at $\mathrm{pH}$ 6.6. Nonetheless, 6 out of the 17 studied LAB isolates $(L$. plantarum TL-1, I-UL4, RI 11, RG 11, RG 14 \& RS 5) exhibited significantly higher $(P<0.05)$ extracellular proteolytic activity in the alkaline environment in this study. Production of alkaline proteases by various LAB including L. plantarum [53], P. pentosaceus [54], L. helveticus [55], and S. thermophiles [56] was well documented. Interestingly, the other 9 LAB isolates displayed comparably high level of extracellular proteolytic activity in both acidic and alkaline conditions as compared to their proteolytic activity at pH 6.5. Results obtained in the quantitative assay suggested that $\mathrm{pH}$ exerted a great impact on the activity of extracellular proteases produced by the studied LAB. The pronounced effect of $\mathrm{pH}$ on proteolytic activity was probably due to the alteration of hydrogen-ion equilibrium, which consequently modified the active structure of the enzyme or altered the protonation state of the substrate, hence affected the overall proteolytic activity [57].
Among the 17 studied LAB isolates, L. plantarum RG14 demonstrated the highest extracellular proteolytic activity in both acidic and alkaline environment with a specific extracellular proteolytic activity of 15.76 $\mathrm{U} / \mathrm{mg}$ and $19.42 \mathrm{U} / \mathrm{mg}$ respectively. However, the extracellular proteolytic activity recorded by $L$. plantarum RG14 in acidic condition was not significantly different $(P>0.05)$ from L. plantarum TL-1. Meanwhile, L. plantarum RI11 and L. plantarum RS5 produced comparable strength of extracellular proteolytic activity in alkaline condition in comparison to $L$. plantarum RG14, whereby there was no significant difference $(P>0.05)$ between the extracellular proteolytic activities of the three isolates in $\mathrm{pH} 8$. Nevertheless, significantly higher $(P<0.05)$ extracellular proteolytic activity at pH 6.5 was detected in L. plantarum RS5 and L. plantarum RI11 among all the tested LAB isolates, with an activity of approximately $17 \mathrm{U} / \mathrm{mg}$.

The occurrence of extracellular proteolytic under broad $\mathrm{pH}$ conditions implied that the studied $\mathrm{LAB}$ isolates produced and secreted more than one extracellular protease isozymes. Thung [31] also reported similar findings, where $\mathrm{LAB}$ isolated from various Malaysian fermented foods demonstrated versatile proteolytic activities that active over a broad $\mathrm{pH}$ conditions and up to 4 different protease isozymes were identified upon purification by using Fast Protein Liquid Chromatography. Moreover, Rodarte et al. [58] reported that numerous bacteria and filamentous fungi are capable of producing proteolytic activity in more than one $\mathrm{pH}$ conditions. Hence, the versatile extracellular proteolytic activity of the LAB isolates could be exploited as an effective bio-agent for extracellular production of AA. 


\section{Amino acid production profile of $L A B$ isolates}

The 17 LAB isolates that possessed versatile proteolytic system were determined subsequently for their ability to produce AA extracellularly. Results obtained in this study showed that all the 17 studied LAB isolates have the capability to produce an array of amino acids extracellularly, where increased concentration of various AA were detected (Table 2). In contrast, the AA profile of control remained unchanged throughout $24 \mathrm{~h}$ of incubation (Table 2), inferring that the increment of AA content was due to the presence of LAB and their versatile extracellular proteolytic activities. In comparison, the production of glutamate and valine was detected for all the studied LAB isolates, except for L. plantarum RI11 that only produced glutamate. Glutamate and valine productions by LAB were also reported for fish silage treated with Lactobacillus pentosus and L. plantarum [25], cassava wastes treated with Lactobacillus delbrueckii and Lactobacillus coryneformis [59], as well as cow's milk fermented with $L$. delbrueckii subsp. bulgaricus, Lactobacillus helveticus, Lactococcus lactis subsp. lactis, and Streptococcus thermophilus [24]. Moreover, Vidotti et al. [26] also reported the increased glutamate content in fermented fish silage treated with L. plantarum but valine production was not detected.

In contrast, the studied $\mathrm{LAB}$ isolates did not show the ability to produce arginine, whereby all the tested LAB isolates displayed a reducing arginine profile. Consumption of arginine by Lactobacillus sp. has been reported by Lee et al. [60], where a drastic reduction of arginine content was observed, suggesting that arginine plays a crucial role in ensuring the survival of LAB [61]. Manca de Nadra et al. [62] reported that some $\mathrm{LAB}$ were capable of degrading L-arginine via Arginine Dihydrolase (ADI) pathway to produce additional energy. Despite contradictory finding reported by Simova et al. [24], where increased arginine content was found in cow's milk fermented with $L$. delbrueckii subsp. bulgaricus, L. lactis subsp. lactis, and $S$. thermophilus, yet the increment was relatively low. Surprisingly, results obtained in this study demonstrated Lactobacillus sp. has great requirement for serine instead of arginine, implying that serine could be one of the essential AA for the growth of Lactobacillus sp. Depletion of serine in $L$. plantarum could be attributed to the action of serine dehydratase that responsible for the deamination of serine into ammonia and pyruvate and ultimately into organic acids [63].

Generally, results obtained in the current study show that each $\mathrm{LAB}$ isolate exhibited different production profile of AA despite they belong to the same species, suggesting that the AA production was strain dependent. For instances, $P$. pentosaceus TB-1 produced comparatively vast quantities of glutamate and leucine, while $P$. pentosaceus TP-3 produced relatively high amount of glycine, threonine

Table 2 Amino acids production profile of LAB isolates

\begin{tabular}{|c|c|c|c|c|c|c|c|c|c|c|c|c|c|c|c|c|c|c|}
\hline \multirow[t]{2}{*}{ Isolates } & \multicolumn{18}{|c|}{ Amino acids } \\
\hline & Asp & Glu & Asn & Ser & Gly & Thr & Arg & Ala & Tyr & Cy2 & Val & Met & Trp & Phe & Ile & Leu & Lys & Pro \\
\hline P. pentosaceus B12m9 & - & ++ & - & + & + & + & - & + & + & + & + & + & - & - & + & + & - & + \\
\hline P. pentosaceus TB-1 & + & ++ & + & + & + & + & - & + & - & + & + & + & - & + & + & ++ & - & + \\
\hline P. pentosaceus TL-3 & - & ++ & - & + & + & ++ & - & - & - & + & + & + & - & + & ++ & +++ & - & ++ \\
\hline P. pentosaceus TP-3 & - & +++ & - & + & ++ & ++ & - & + & - & + & ++ & + & - & + & + & +++ & - & + \\
\hline P. pentosaceus TP-4 & - & + & - & - & + & + & - & - & - & + & + & + & - & + & + & + & - & + \\
\hline P. pentosaceus TP-8 & - & ++ & - & + & + & + & - & + & - & + & + & + & - & - & + & - & - & + \\
\hline P. acidilactici TB-2 & - & ++ & - & + & + & ++ & - & + & - & + & + & + & - & + & +++ & +++ & - & ++ \\
\hline P. acidilactici TP-6 & + & + & - & - & + & + & - & - & - & + & + & - & + & +++ & + & - & - & ++ \\
\hline L. plantarum TL-2 & - & + & - & - & - & - & - & - & - & - & + & - & - & - & - & - & - & - \\
\hline L. plantarum TP-2 & - & + & - & - & + & + & - & - & - & - & + & - & - & - & + & ++ & - & - \\
\hline L. plantarum TP-5 & - & + & - & - & + & - & - & - & - & - & + & - & - & - & - & - & - & + \\
\hline L. plantarum TL-1 & - & ++ & - & - & + & + & - & - & - & - & + & - & - & - & - & - & - & + \\
\hline L. plantarum I-UL4 & - & ++ & - & - & - & - & - & - & - & + & + & - & - & + & - & - & + & - \\
\hline L. plantarum RI11 & - & + & - & - & - & - & - & - & - & - & - & - & - & - & - & - & - & - \\
\hline L. plantarum RG11 & - & ++ & - & - & + & - & - & - & - & - & + & - & - & - & - & - & - & - \\
\hline L. plantarum RG14 & - & + & - & - & + & - & - & - & - & - & + & - & - & - & - & - & - & - \\
\hline L. plantarum RS5 & - & + & - & - & + & - & - & - & - & - & + & + & - & - & - & - & - & + \\
\hline Control & 0 & 0 & 0 & 0 & 0 & 0 & 0 & 0 & 0 & 0 & 0 & 0 & 0 & 0 & 0 & 0 & 0 & 0 \\
\hline
\end{tabular}

'+' indicates $0.1-50 \mathrm{mg} / \mathrm{L}$ increment; ' $++^{\prime}$ indicates $50.1-100 \mathrm{mg} / \mathrm{L}$ increment; ' $+++{ }^{\prime}$ indicates $>100 \mathrm{mg} / \mathrm{L}$ increment; '-' indicates $0.1-50 \mathrm{mg} / \mathrm{L} \mathrm{decrement;} \mathrm{'--'}$ indicates 50.1-100 mg/L decrement; '---' indicates $>100 \mathrm{mg} / \mathrm{L}$ decrement; ' 0 ' indicates neither significant $(P<0.05)$ increment nor decrement 
and valine in addition to glutamate and leucine. Nevertheless, profound differences between the AA production profiles of LAB from different genus were noted in this study (Table 2). Comparing between the two main LAB genera of LAB employed in present study, Pediococcus sp. demonstrated relatively higher AA production ability, whereby all the Pediococcus strains produced between 10 and 14 types of AA and all the Lactobacillus strains produced between 1 and 6 types of AA in lower quantity (Table 2).

Despite Lactobacillus strains used in the present study exhibited comparatively higher extracellular proteolytic activity as compared to the Pediococci, yet the AA production profile was in a dramatic reverse feature. This might be attributed to the production of different proteolytic enzymes by different LAB species [44]. The release of AA from proteins relies heavily on the action of aminopeptidases that responsible for the cleavage of AA from $\mathrm{N}$-terminus of peptides to liberate free AA. Pediococcus sp. were reported to exhibit high aminopeptidase activity in a study conducted by Vafopoulou-Mastrojiannaki et al. [64], where all the 10 Pediococci showed relatively high aminopeptidase activity. Similarly, Carafa et al. [65] also demonstrated that four $P$. pentosaceus isolated from spontaneously fermented mountain cheese exhibited superior aminopeptidase activity from 300 to $750 \mathrm{U} / \mathrm{mg}$, whereas the aminopeptidase activity of the L. plantarum was comparably lower. In addition, Mtshali et al. [66] showed that various peptidases genes including pepC, pepI, pepN, pepM and pepT were present in all the tested $P$. pentosaceus and $P$. acidilactici. However, not all the tested $L$. plantarum possessed the peptidase genes.

Another possible explanation for none correlation between AA production and extracellular proteolytic activity could be attributed to the mechanisms involved in the production of AA. Generally, production of AA may occur through biodegradation pathway involving extracellular proteolysis of proteins by extracellular proteolytic enzymes or intracellular biosynthetic pathway involving biosynthesis from AA precursors. Therefore, LAB isolates might produce AA via biosynthetic pathways or a combination of both biosynthetic and biodegradation pathways instead of biodegradation pathway or biosynthetic pathway alone. Numerous studies [28, 67-69] have reported the presence of genes encoded for enzymes involved in biosynthesis of various AA in LAB. The low AA production ability of Lactobacilli could be due to the long-term application of Lactobacilli in food industry, which may lead to adaptation of the species to nutrient rich environment and subsequently resulted in lost or degenerated AA biosynthetic ability [68, 70]. Klaenhammer et al. [52] reported that Lactobacillus sp. possessed disrupted AA synthesis pathway; hence, their AA requirement is often compensated with pronounced proteolytic activity to obtain AA from the habitat.

\section{Production of feed amino acids}

It is noteworthy that the studied LAB isolates showed promising potential to produce various AA including feed supplement AA that are used exclusively in livestock industry such as methionine, lysine, threonine and tryptophan (Table 2). Out of the 17 tested LAB isolates, 8 of the LAB isolates including $\mathrm{B} 12 \mathrm{~m} 9$, TB- 1 , TL-3, TP-3, TP-4, TP-8, TB-2 and RS5 were capable of producing methionine (Table 2). The methionine production profile of the $8 \mathrm{LAB}$ isolates is depicted in Fig. 3, whereby TB-1, TL-3, TP-3, TP-8 and RS5 isolates produced methionine from the beginning of cultivation until $12-14 \mathrm{~h}$ of incubation, whereas the methionine

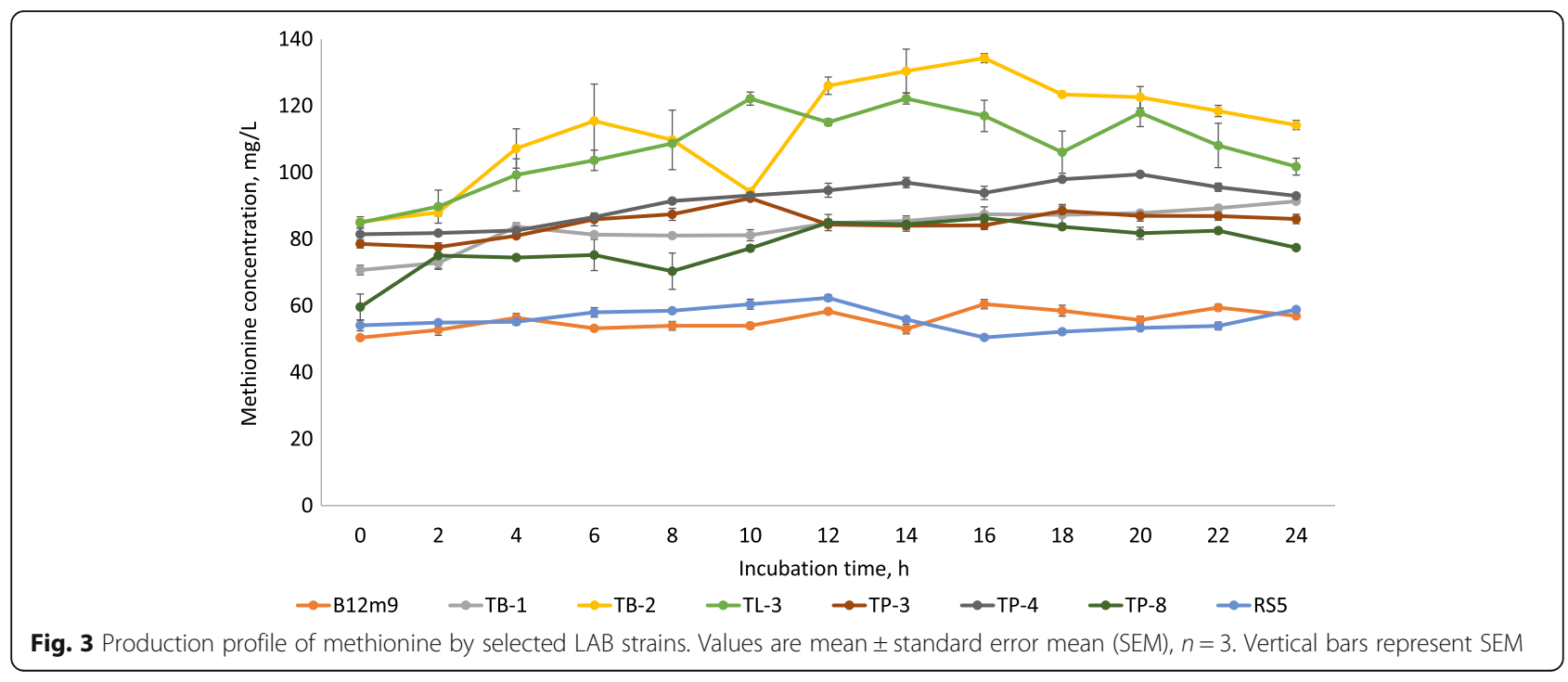


Table 3 Kinetic parameters of methionine and lysine productions by selected LAB strains

\begin{tabular}{|c|c|c|c|c|c|c|}
\hline \multirow[t]{2}{*}{ Isolates } & \multicolumn{3}{|c|}{ Methionine } & \multicolumn{3}{|c|}{ Lysine } \\
\hline & $\mathrm{T}, \mathrm{h}$ & Net methionine concentration, mg/L & $P_{r}, \mathrm{mg} / \mathrm{L} / \mathrm{h}$ & $T, h$ & Net lysine concetration, mg/L & $P_{r}, \mathrm{mg} / \mathrm{L} / \mathrm{h}$ \\
\hline P. pentosaceus B12m9 & 16 & 10.08 & 0.63 & - & - & - \\
\hline P. pentosaceus TB-1 & 24 & 20.64 & 0.86 & - & - & - \\
\hline P. pentosaceus TL-3 & 10 & 37.21 & 3.72 & - & - & -- \\
\hline P. pentosaceus TP-3 & 10 & 13.72 & 1.37 & - & - & - \\
\hline P. pentosaceus TP-4 & 20 & 17.99 & 0.90 & - & - & - \\
\hline P. pentosaceus TP-8 & 16 & 26.71 & 1.67 & - & - & - \\
\hline P. acidilactici TB-2 & 16 & 49.14 & 3.07 & - & - & - \\
\hline L. plantarum RS5 & 12 & 8.28 & 0.69 & - & - & - \\
\hline L. plantarum I-UL4 & - & - & - & 6 & 7.44 & 1.24 \\
\hline
\end{tabular}

production by $\mathrm{B} 12 \mathrm{~m} 9$ and $\mathrm{TB}-2$ isolates were extended until $16 \mathrm{~h}$ of incubation and $20 \mathrm{~h}$ of incubation for TP-4 isolate. Thereafter, the methionine content reduced slowly or remained plateau. The highest production of methionine was recorded by $P$. acidilactici TB-2, followed by $P$. pentosaceus TL-3 and $P$. pentosaceus TP-8 with $49.14 \mathrm{mg} / \mathrm{L}, 37.23 \mathrm{mg} / \mathrm{L}$ and $26.71 \mathrm{mg} / \mathrm{L}$ net increment of methionine content respectively. Methionine production was also reported by Simova et al. [24] in cow's milk fermented with $L$. delbrueckii subsp. bulgaricus, L. helveticus, L. lactis subsp. lactis, and S. thermophilus, yet the production was relatively low with merely $4.2 \mathrm{mg} / \mathrm{L}$ of methionine production was detected. The methionine production kinetic parameter by the 8 $\mathrm{LAB}$ producer strains are shown in Table 3 . Among the 8 methionine producing LAB, $P$. pentosaceus TL- 3 demonstrated the highest methionine productivity of 3.72 $\mathrm{mg} / \mathrm{L} / \mathrm{h}$, followed by $P$. acidilactici TB-2 $(3.07 \mathrm{mg} / \mathrm{L} / \mathrm{h})$. Despite $P$. acidilactici TB-2 produced the highest amount of net methionine yet the productivity was slightly lower than $P$. pentosaceus TL-3 due to the longer incubation time required to achieve the highest methionine production.

In comparison, lysine production was only detected in L. plantarum I-UL4 with relatively low percentage of increment $(2.5 \%)$, whereby the lysine content was increased from $296.31 \mathrm{mg} / \mathrm{L}$ at the beginning of cultivation to $303.76 \mathrm{mg} / \mathrm{L}$ at $6 \mathrm{~h}$ of incubation. The net increment of lysine was $7.44 \mathrm{mg} / \mathrm{L}$ (Fig. 4) and the lysine productivity was $1.24 \mathrm{mg} / \mathrm{L} / \mathrm{h}$ (Table 3 ). Odunfa et al. [71] also reported extracellular lysine production by Lactobacillus sp., whereby up to $86 \mathrm{mg} / \mathrm{L}$ of extracellularlysine production was detected. The lysine production recorded by $L$. plantarum I-UL4 in the current study is relatively low as compared to those reported by Odunfa et al. [71].

Among the LAB isolates, tryptophan production was only detected in P. acidilactici TP-6, whereby the tryptophan content was increased slowly from the beginning

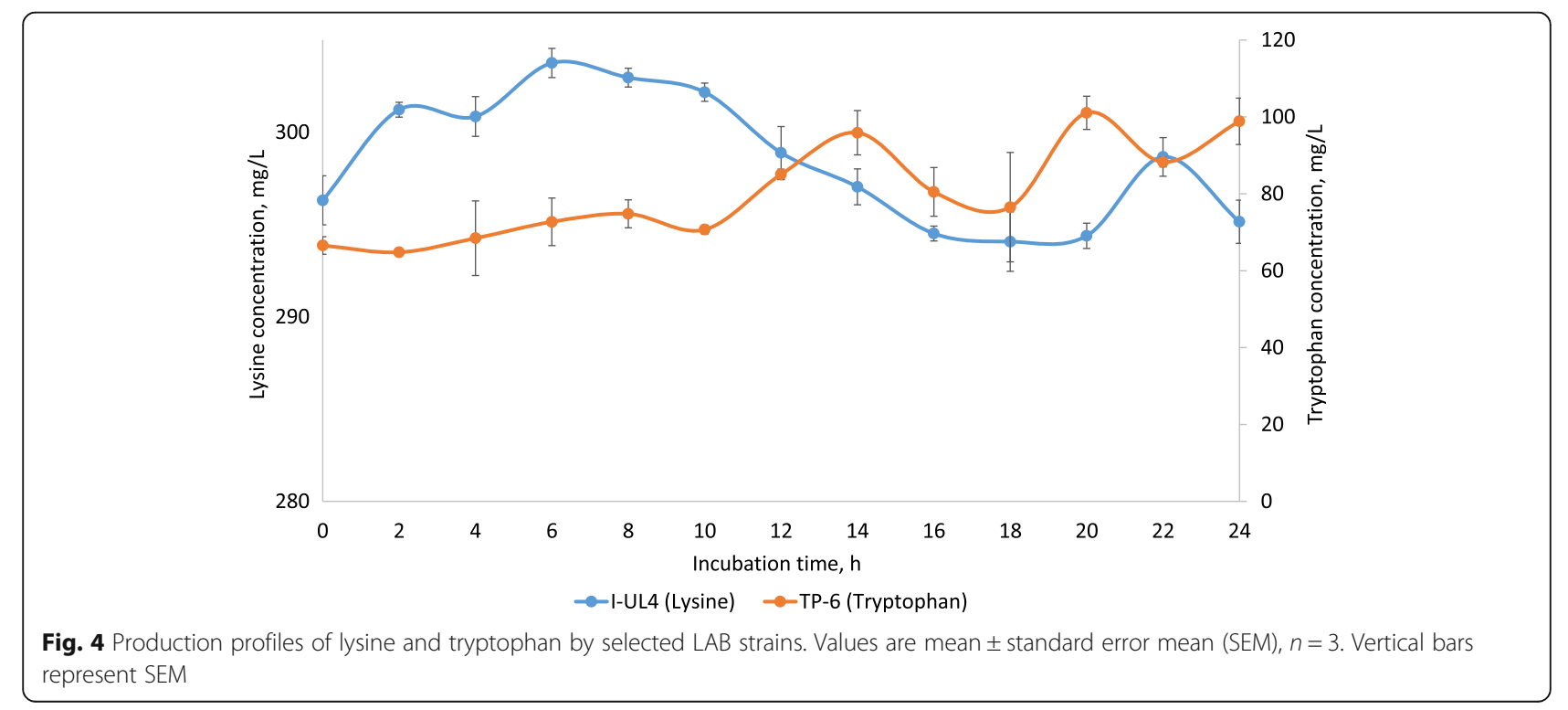


Table 4 Kinetic parameters of threonine and tryptophan productions by selected LAB strains

\begin{tabular}{|c|c|c|c|c|c|c|}
\hline \multirow[t]{2}{*}{ Isolates } & \multicolumn{3}{|c|}{ Threonine } & \multicolumn{3}{|c|}{ Tryptophan } \\
\hline & $\mathrm{T}, \mathrm{h}$ & Net threonine concentration, mg/L & $P_{r}, \mathrm{mg} / \mathrm{L} / \mathrm{h}$ & $\mathrm{T}, \mathrm{h}$ & Net tryptophan concentration, mg/L & $P_{r}, \mathrm{mg} / \mathrm{L} / \mathrm{h}$ \\
\hline P. pentosaceus B12m9 & 22 & 30.20 & 1.37 & - & - & - \\
\hline P. pentosaceus TB-1 & 24 & 41.31 & 1.72 & - & - & - \\
\hline P. pentosaceus TL-3 & 10 & 55.80 & 5.58 & - & - & - \\
\hline P. pentosaceus TP-3 & 16 & 52.75 & 3.30 & - & - & - \\
\hline P. pentosaceus TP-4 & 10 & 15.46 & 1.55 & - & - & - \\
\hline P. pentosaceus TP-8 & 16 & 18.58 & 1.16 & - & - & - \\
\hline P. acidilactici TB-2 & 18 & 58.41 & 3.25 & - & - & - \\
\hline P. acidilactici TP-6 & 18 & 29.79 & 1.66 & 20 & 34.51 & 1.73 \\
\hline L. plantarum TL-1 & 16 & 11.55 & 0.72 & - & - & - \\
\hline L. plantarum TP-2 & 22 & 8.11 & 0.37 & - & - & - \\
\hline
\end{tabular}

of incubation until $8 \mathrm{~h}$ of incubation. Thereafter, the production of tryptophan increased drastically up to $14 \mathrm{~h}$, followed by a steep reduction until $18 \mathrm{~h}$ of incubation. Subsequently, the tryptophan content was increased tremendously to approximately $100 \mathrm{mg} / \mathrm{L}$ and maintained until the end of incubation (Fig. 4). Up to $51.84 \%$ increment of tryptophan content was detected at $20 \mathrm{~h}$ of incubation, which was equivalent to a net increment of $34.51 \mathrm{mg} / \mathrm{L}$ and a productivity of $1.73 \mathrm{mg} / \mathrm{L} / \mathrm{h}$ (Table 4 ). Tryptophan production by $L$. delbrueckii subsp. bulgaricus in cow's milk was reported by Simova et al. [24] but the production was relatively low $(7.4 \mathrm{mg} / \mathrm{L}$ of tryptophan was produced). Similarly, the production of tryptophan recorded by $P$. acidilactici TP- 6 in the current study was approximately 10 fold higher as compared to the tryptophan production by Lactobacilli in a study conducted by Tarek and Hesham [72]. Contradictorily, tryptophan production was not detected in fish silage treated with L. plantarum [26].
Interestingly, $59 \%$ of the studied LAB isolates demonstrated relatively prodigious ability to produce threonine with highest production recorded by $P$. acidilactici TB-2 and P. pentosaceus TL-3 (Fig. 5). The former produced a net increment of $58.41 \mathrm{mg} / \mathrm{L}$, whereby the threonine content was increased from $72.58 \mathrm{mg} / \mathrm{L}$ from beginning of incubation up to $130.99 \mathrm{mg} / \mathrm{L}$ at $18 \mathrm{~h}$ of incubation. Meanwhile, $P$. pentosaceus TL-3 produced $55.80 \mathrm{mg} / \mathrm{L}$ of net threonine, resulting in a final threonine concentration of $128.78 \mathrm{mg} / \mathrm{L}$ at $10 \mathrm{~h}$ of incubation. Contradictory, the threonine production by L. lactis subsp. lactis, S. thermophilus [24] and Lactobacillus sp. [72] was comparatively low, ranging from 0.4-8 $\mathrm{mg} / \mathrm{L}$. Among the 10 threonine producing LAB, P. pentosaceus TL-3 demonstrated the highest threonine productivity $\left(P_{r}\right)$ of $5.58 \mathrm{mg} / \mathrm{L} / \mathrm{h}$ (Table 4$)$. Despite $P$. acidilactici TB-2 produced higher amount of threonine as compared to $P$. pentosaceus TL-3, yet the time required by the isolate to achieve the highest production was much longer than

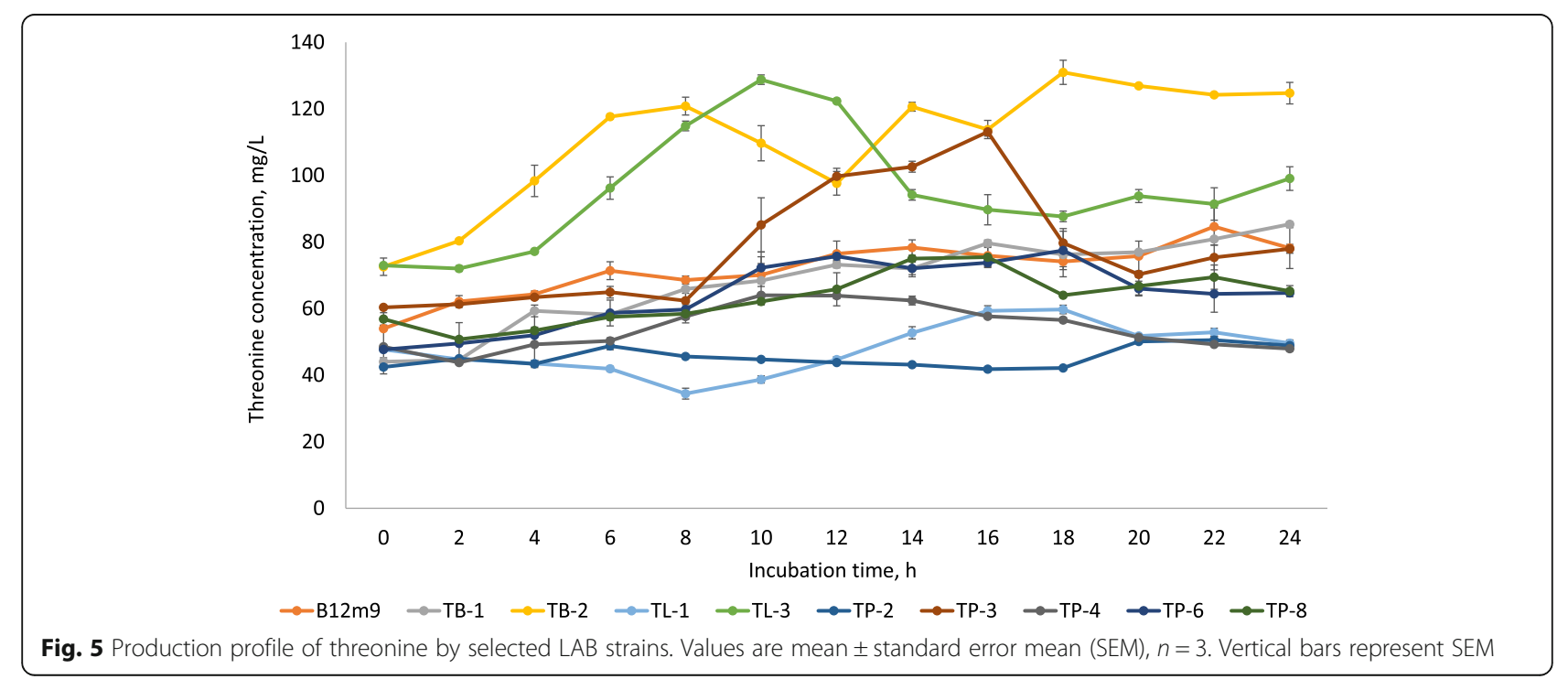


P. pentosaceus TL-3. Consequently, the productivity of $P$. acidilactici TB-2 was nearly 1.8 fold lower than the threonine productivity of $P$. pentosaceus TL-3.

\section{Conclusions}

All the 17 studied LAB isolates possessed versatile extracellular proteolytic activities that active over a broad $\mathrm{pH}$ range. The highest proteolytic activity of $15.76 \mathrm{U} / \mathrm{mg}$ and $19.42 \mathrm{U} /$ mg was achieved by L. plantarum RG14 at $\mathrm{pH} 5$ and $\mathrm{pH} 8$ respectively, while $L$. plantarum RS5 showed the highest proteolytic activity at $\mathrm{pH} 6.5(17.22 \mathrm{U} / \mathrm{mg})$. Generally, the studied LAB isolates have the capability of producing an array of AA including a few major feed supplement AA such as methionine, lysine, threonine and tryptophan. However, the AA production was strain dependent, where different isolates exhibited different preference and efficiency in AA production. Furthermore, Pediococcus sp. demonstrated greater AA production ability in comparison to Lactobacillus sp. despite the proteolytic activity was a completely reversal manner, implying the proteolytic activity did not correlate with the AA production capability. Additionally, the production of AA by the LAB isolates might occur through biosynthetic pathway or a combination of biosynthetic and biodegradation pathways, which will require further study to elucidate the mechanism of AA production mediated by studied LAB. In comparison, $P$. pentosaceus TL-3 recorded the highest methionine and threonine productivity of $3.72 \mathrm{mg} / \mathrm{L} / \mathrm{h}$ and $5.58 \mathrm{mg} / \mathrm{L} / \mathrm{h}$ respectively, whereas $L$. plantarum I-UL4 demonstrated a lysine productivity of $1.24 \mathrm{mg} / \mathrm{L} / \mathrm{h}$ and $P$. acidilactici TP-6 achieved up to $1.73 \mathrm{mg} / \mathrm{L} / \mathrm{h}$ of tryptophan productivity. Obviously all the 17 studied LAB isolates exhibited versatile extracellular proteolytic activities and hence they possessed vast potential as a bio-agent for the productions of various bioactive peptides and AA extracellularly as feed supplements.

\section{Abbreviations \\ AA: Amino acids; ANOVA: Analysis of variance; CFS: Cell-free-supernatant; CFU/mL: Colony forming unit per millilitre; FMOC: 9-fluorenylmethyl chloroformate; GRAS: Generally Recognised as Safe; HPLC: High performance liquid chromatograph; L. plantarum: Lactobacillus plantarum; LAB: Lactic acid bacteria; Lactobacillus sp.: Lactobacillus species; MRS: De Man, Rogosa and Sharpe; OPA: O-phthalaldehyde; P. acidilactici: Pediococcus acidilactici; P. pentosaceus: Pediococcus pentosaceus; Pediococcus sp.: Pediococcus species; SMAWD: Skim milk agar well diffusion}

\section{Acknowledgements}

The authors would like to thank Ministry of Education of Malaysia for funding the research grant under Long-Term Research Grant Scheme (LRGS).

\section{Funding}

The Long-Term Research Grant (LRGS) of the Ministry of Education of Malaysia supported this work.

\section{Availability of data and materials}

The datasets used and/or analysed during this study are available from the corresponding author on reasonable request.

\section{Authors' contributions}

YHL carried out the current study and drafted the manuscript. HLF participated in the design, conceived and coordination of this study; and helped to draft and revised the manuscript. TCL participated in the design of the study and performed the statistical analysis. RM participated in the design of the production profile and kinetic analyses of amino acid productions. NA helped to draft and revise the manuscript. All authors read and approved the final manuscript.

\section{Authors' information}

YHL was a PhD student who has conducted the current study. HLF, TCL, RM and NA are collaborators of the research funding used for the experimental work presented in this report. HLF is a professor in the Department of Bioprocess Technology, Faculty of Biotechnology and Biomolecular Sciences, Universiti Putra Malaysia, 43400 UPM Serdang, Selangor, Malaysia. TCL is a professor in the Department of Animal Science, Faculty of Agriculture, Universiti Putra Malaysia, 43400 UPM Serdang, Selangor, Malaysia. RM is a professor in the Department of Bioprocess Technology, Faculty of Biotechnology and Biomolecular Sciences, Universiti Putra Malaysia, 43400 UPM Serdang, Selangor, Malaysia. NA is a research fellow in the Institute of Tropical Agriculture and Food Security, Universiti Putra Malaysia, 43400 UPM Serdang, Selangor, Malaysia.

Ethics approval and consent to participate

Not applicable.

\section{Consent for publication}

Not applicable.

\section{Competing interests}

The authors declare that they have no competing interests.

\section{Author details}

${ }^{1}$ Institute of Bioscience, Universiti Putra Malaysia, 43400 UPM, Serdang, Selangor, Malaysia. ${ }^{2}$ Department of Bioprocess Technology, Faculty of Biotechnology and Biomolecular Sciences, Universiti Putra Malaysia, 43400 UPM, Serdang, Selangor, Malaysia. ${ }^{3}$ Department of Animal Sciences, Faculty of Agriculture, Universiti Putra Malaysia, 43400 UPM, Serdang, Selangor, Malaysia. ${ }^{4}$ Institute of Tropical Agriculture and Food Security, Universiti Putra Malaysia, 43400 UPM, Serdang, Selangor, Malaysia. ${ }^{5}$ Institute of Tropical Forestry and Forest Products, Universiti Putra Malaysia, 43400 UPM, Serdang, Selangor, Malaysia.

Received: 1 October 2018 Accepted: 14 January 2019

Published online: 07 March 2019

\section{References}

1. Sundrum A, Schneider K, Richter U. Possibilities and limitations of protein supply in organic poultry and pig production. In: Report of the EU-project, Research to Support Revision of the EU Regulation on Organic Agriculture, no. SSPE-CT-2004-502397. 2005. http://orgprints.org/10983/1/Final_Report_ EC_Revision.pdf. Accessed 19 Jan 2019.

2. Leuchtenberger W, Huthmacher K, Drauz K. Biotechnological production of amino acids and derivatives: current status and prospects. Appl Microbiol Biotechnol. 2005;69(1):1-8.

3. Kircher M, Pfefferle W. The fermentative production of L-lysine as an animal feed additive. Chemosphere. 2001;43:27-31.

4. Dong X, Quinn PJ, Wang X. Metabolic engineering of Escherichia coli and Corynebacterium glutamicum for the production of L-threonine. Biotechnol Adv. 2011;29(1):11-23.

5. Bunchasak C. Role of dietary methionine in poultry production. J Poult Sci. 2009;46(3):169-79.

6. Święch E, Boryczka M, Taciak M, Buraczewska L. The effect of graded levels of dietary threonine on nitrogen retention and structure of the small intestine in young pigs. J Anim Feed Sci. 2011;20:350-60.

7. Duarte KF, Junqueira OM, Filardi RDS, Siqueira JCD, Puzotti MM, Garcia EA, et al. Digestible tryptophan requirements for broilers from 22 to 42 days old. Rev Bras Zootec. 2013;42(10):728-33.

8. Lessire M, Hallouis JM, Bordeau T, Primot Y, Corrent E, Fraysse P, et al. Study of the lysine requirement of broiler finishers: effects on growth performance. In: Actes des 10èmes Journées de la Recherche Avicole et 
Palmipèdes à Foie Gras; La Rochelle. France: Institut Technique de l'Aviculture; 2013. p. 749-52.

9. Imuji TC, Akinmutimi AH, Ogbuewu IP, Etuk IF, Odoemelam VU. Roles of tryptophan in monogastric nutrition: a review. Adv Agric Sci Eng Res. 2014; 4(3):1544-56.

10. Xie M, Zhang L, Wen ZG, Tang J, Huang W, Hou SS. Threonine requirement of white Pekin ducks from hatch to 21 d of age. Brit Poultry Sci. 2014; 55(4):553-7.

11. Kim JH, Patterson PH, Kim WK. Impact of dietary crude protein, synthetic amino acid and keto acid formulation on nitrogen excretion. Int J Poult Sci. 2014;13(8):429-36.

12. Ikeda M. Amino acid production processes. In: Faurie R, Thommel J, editors. Advances in Biochemical Engineering Biotechnology: Microbial production of L-amino acids. Berlin: Springer Berlin Heidelberg; 2003. p. 1-35.

13. Eisenstein B, Zaleznik D. Enterobacteriiaceae. In: Bennett JE, Dolin R, Blaser MJ, editors. Mandell, Douglas, \& Bennett's principles and practice of infectious diseases. Philadelphia: Elsevier Saunders; 2000. p. 2294-310.

14. Mayo B, Aleksandrzak-Piekarczyk T, Fernandez M, Kowalczyk M, AlvarezMartin P, Bardowski J. Updates in the metabolism of lactic acid bacteria. In: Mozzi F, Raya RR, Vignola GM, editors. Biotechnology of lactic acid Bacterianovel applications. New Jersey: Wiley-Blackwell; 2010. p. 3-33.

15. Hill C, Guarner F, Reid G, Gibson GR, Merenstein DJ, Pot B, et al. The international scientific Association for Probiotics and Prebiotics consensus statement on the scope and appropriate use of the term probiotic. Nat Rev Gastroenterol Hepatol. 2014;11(8):506.

16. Loh TC, Lee TM, Foo HL, Law FL, Rajion MA. Growth performance and fecal microflora of rats offered metabolites from lactic acid bacteria. J Appl Anim Res. 2008;34(1):61-4.

17. Loh, TC, Choe DW, Foo HL, Awis QS, Hair-Bejo M. Effects of feeding different postbiotic metabolite combinations produced by Lactobacillus plantarum strains on egg quality and production performance, faecal parameters and plasma cholesterol in laying hens. BMC Vet Res. 2014;10(149):1-9.

18. Loh TC, Chong SW, Foo HL, Law FL. Effects on growth performance, faecal microflora and plasma cholesterol after supplementation of spray-dried metabolite to postweaning rats. Czech J Animal Sci. 2009:54(No. 1):10-6.

19. Thanh NT, Chwen LT, Foo HL, Hair-Bejo M, Kasim AB. Inhibitory activity of metabolites produced by strains of Lactobacillus plantarum isolated from Malaysian fermented food. Int J Probiotics Prebiotics. 2010;5(1):37-43.

20. Kareem KY, Loh TC, Foo HL, Henny A and Samsudin AA. Effects of dietary postbiotic and inulin on growth performance, IGF1 and GHR mRNA expression, faecal microbiota and volatile fatty acids in broilers. BMC Vet Res. 2016;12(163):1-10

21. Kareem $K$, Ling FH, Chwen LT, Foong OM, Asmara SA. Inhibitory activity of postbiotic produced by strains of Lactobacillus plantarum using reconstituted media supplemented with inulin. Gut Pathogens. 2014;6(1):23.

22. Collado MC, Meriluoto J, Salminen S. Role of commercial probiotic strains against human pathogen adhesion to intestinal mucus. Lett Appl Microbiol. 2007:45(4):454-60.

23. Savijoki K, Ingmer $\mathrm{H}$, Varmanen P. Proteolytic systems of lactic acid bacteria. Appl Microbiol Biotechnol. 2006;71:394-406.

24. Simova E, Simov Z, Beshkova D, Frengova G, Dimitrov Z, Spasov Z. Amino acid profiles of lactic acid bacteria, isolated from kefir grains and kefir starter made from them. Int J Food Microbiol. 2006;107(2):112-23.

25. Hasan B. Fermentation of fish silage using Lactobacillus pentosus. J Natur Indones. 2003;6(1):11-5.

26. Vidotti RM, Viegas EMM, Carneiro DJ. Amino acid composition of processed fish silage using different raw materials. Anim Feed Sci Technol. 2003;105(1): 199-204.

27. Zareian M, Ebrahimpour A, Bakar FA, Mohamed AKS, Forghani B, Ab-Kadir MSB, et al. A glutamic acid-producing lactic acid bacteria isolated from Malaysian fermented foods. Int J Mol Sci. 2012;13(5):5482-97.

28. Garault $P$, Letort $C$, Juillard V, Monnet V. Branched-chain amino acid biosynthesis is essential for optimal growth of Streptococcus thermophilus in milk. Appl Environ Microbiol. 2000;66(12):5128-33.

29. Lee YA. Purification and characterisation of bacteriocin produced by Lactococcus lactis subsp. lactis RW18 isolated from steamed fish (Rastrelliger sp.). Master thesis. Malaysia: Universiti Putra Malaysia; 2002.

30. Lim YS. Isolation of bacteriocinogenic lactic acid bacteria and purification of selected bacteriocins from traditional fermented foods. Master thesis. Malaysia: Universiti Putra Malaysia; 2003.
31. Thung TY. Isolation and purification of proteolytic enzyme produced by lactic acid bacteria from budu and bambangan. Master thesis. Malaysia: Universiti Putra Malaysia; 2012.

32. Foo HL, Loh TC, Lai PW, Lim YS, Kufli CN, Gulam R. Effects of adding Lactobacillus plantarum I-UL4 metabolites in drinking water of rats. Pakistan J Nutr. 2003:2(5):283-8.

33. Bradford MM. A rapid and sensitive method for the quantitation of microgram quantities of protein utilizing the principle of protein-dye binding. Anal Biochem. 1976;72:248-54.

34. Norfarina MN, Loh TC, Raha AR, Foo HL, Zuhainis WS, Rosfarizan M. Evaluation of lactic acid bacteria as amino acid producer for poultry feed additive formulation. In: Proceedings of the 1st ASEAN Regional Conference on Animal Production \& the 35th Annual Conference of Malaysian Society of Animal Production; Kuching. Malaysia: Malaysian Society of Animal Production; 2014

35. Henderson JW, Ricker RD, Cliff WI. Rapid, accurate, sensitive and reproducible HPLC analysis of amino acids. Agilent Technologies; 2000. p. 5980-1193.

36. Smit G, Smit BA, Engels WJ. Flavour formation by lactic acid bacteria and biochemical flavour profiling of cheese products. FEMS Microbiol Rev. 2005; 29(3):591-610.

37. Chen YS, Steele JL. Genetic characterization and physiological role of endopeptidase O from Lactobacillus helveticus CNRZ32. Appl Environ Microbiol. 1998;64(9):3411-5

38. Kunji ER, Mierau I, Hagting A, Poolman B, Konings WN. The proteotytic systems of lactic acid bacteria. Antonie Leeuwenhoek. 1996;70(2-4):187-221.

39. Pailin T, Kang DH, Schmidt K, Fung DYC. Detection of extracellular bound proteinase in EPS-producing lactic acid bacteria cultures on skim milk agar. Lett Appl Microbiol. 2001;33(1):45-9.

40. Marroki A, Bousmaha-Marroki L. Lactobacilli isolated from Algerian goat's milk as adjunct culture in dairy products. Braz Arch Biol Techn. 2014;57(3): 410-20.

41. El-Ghaish S, Dalgalarrondo M, Choiset Y, Sitohy M, Ivanova I, Haertlé T, et al. Characterization of a new isolate of Lactobacillus fermentum IFO 3956 from Egyptian Ras cheese with proteolytic activity. Eur Food Res Technol. 2010; 230(4):635-43.

42. Hanan SA. Isolation and screening of extracellular proteases produced by new isolated Bacillus sp. J Appl Pharm Sci. 2012;2(9):71-4.

43. Beganović J, Kos B, Pavunc AL, Uroić K, Džidara P, Šušković J. Proteolytic activity of probiotic strain Lactobacillus helveticus M92. Anaerobe. 2013;20:58-64

44. Donkor ON, Henriksson A, Vasiljevic T, Shah NP. Proteolytic activity of dairy lactic acid bacteria and probiotics as determinant of growth and in vitro angiotensin-converting enzyme inhibitory activity in fermented milk. Lait. 2007:87(1):21-38.

45. Llorente-Bousquets A, Pérez-Munguía S, Farrés A. Novel extracellular proteolytic activity in Pediococcus acidilactici ATCC 8042. Can J Microbiol. 2008:54(8):694-9.

46. Addi N, Guessas B. Characterization of protease activity of Lactococcus lactis species isolated from raw camel's milk. J Biol Sci. 2015;16(6):215-20.

47. Rollán GC, Farias ME, de Nadra MM. Protease production by Leuconostoc oenos strains isolated from wine. World J Microbiol Biotechnol. 1993;9(5): 587-9.

48. Rollán GC, Farías ME, de Nadra MM. Characterization of two extracellular proteases from Leuconostoc oenos. World J Microbiol Biotechnol. 1995;11(2):153-5.

49. de Giori GS, De Valdez GF, de Ruiz Holgado AP, Oliver G. Effect of pH and temperature on the proteolytic activity of lactic acid bacteria. J Dairy Sci. 1985;68(9):2160-4

50. Menconi A, Kallapura G, Latorre JD, Morgan MJ, Pumford NR, Hargis $\mathrm{BM}$, et al. Identification and characterization of lactic acid bacteria in a commercial probiotic culture. Biosci Microbiota Food Health. 2014;33(1):25-30.

51. Oren A. Acidophiles. In: Pettis G, editor. Encyclopedia of life sciences (ELS). Chichester: Wiley; 2010.

52. Klaenhammer TR, Barrangou R, Buck BL, Azcarate-Peril MA, Altermann E. Genomic features of lactic acid bacteria effecting bioprocessing and health. FEMS Microbiol Rev. 2005;29(3):393-409.

53. Essid I, Medini M, Hassouna M. Technological and safety properties of Lactobacillus plantarum strains isolated from a Tunisian traditional salted meat. Meat Sci. 2009;81(1):203-8. 
54. Dalmış Ü, Soyer A. Effect of processing methods and starter culture (Staphylococcus xylosus and Pediococcus pentosaceus) on proteolytic changes in Turkish sausages (sucuk) during ripening and storage. Meat Sci. 2008:80(2):345-54.

55. Valasaki K, Staikou A, Theodorou LG, Charamopoulou V, Zacharaki P, Papamichael EM. Purification and kinetics of two novel thermophilic extracellular proteases from Lactobacillus helveticus, from kefir with possible biotechnological interest. Bioresour Technol. 2008;99(13): 5804-13.

56. Galia W, Perrin C, Genay M, Dary A. Variability and molecular typing of Streptococcus thermophilus strains displaying different proteolytic and acidifying properties. Int Dairy J. 2009;19(2):89-95.

57. Sharma R. Enzyme inhibition: mechanisms and scope. In: Sharma R, editor. Enzyme inhibition and bioapplications. Rijeka: InTech; 2012. p. 3-36.

58. Rodarte MP, Dias DR, Vilela DM, Schwan RF. Proteolytic activities of bacteria, yeasts and filamentous fungi isolated from coffee fruit (Coffea arabica L.). Acta Sci Agron. 2011;33(3):457-64.

59. Aro SO, Aletor VA. Proximate composition and amino acid profile of differently fermented cassava tuber wastes collected from a cassava starch producing factory in Nigeria. Livest Res Rural Dev. 2012;24(3):1-5.

60. Lee K, Lee J, Kim YH, Moon SH, Park YH. Unique properties of four Lactobacilli in amino acid production and symbiotic mixed culture for lactic acid biosynthesis. Curr Microbiol. 2001;43(6):383-90.

61. Chaillou S, Champomier-Vergès MC, Cornet M, Crutz-Le Coq AM, Dudez AM, Martin $\mathrm{V}$, et al. The complete genome sequence of the meat-borne lactic acid bacterium Lactobacillus sakei 23K. Nature Biotechnol. 2005;23(12):1527-33.

62. Manca de Nadra MC. Nitrogen metabolism in lactic acid bacteria from fruits: a review. In: Méndez-Vilas A, editor. Communicating current research and educational topics and trends in applied microbiology. Spain: Formatex; 2007. p. $500-10$

63. Liu SQ, Holland R, McJarrow P, Crow VL. Serine metabolism in Lactobacillus plantarum. Int J Food Microbiol. 2003;89(2):265-73.

64. Vafopoulou-Mastrojiannaki A, Litopoulou-Tzanetaki E, Tzanetakis N Proteinase, peptidase and esterase activity of crude cell-free extracts of Pediococcus pentosaceus isolated from cheese. LWT-Food Sci Technol. 1994; 27(4):342-6.

65. Carafa I, Nardin T, Larcher R, Viola R, Tuohy K, Franciosi E. Identification and characterization of wild Lactobacilli and Pediococci from spontaneously fermented mountain cheese. Food Microbiol. 2015;48:123-32.

66. Mtshali PS, Divol B, du Toit M. Evaluating Lactobacillus and Pediococcus strains for enzyme-encoding genes related to peptide and amino acid utilization in wine. Ann Microbiol. 2013;63(1):233-9.

67. Bardowski J, Ehrlich SD, Chopin A. Tryptophan biosynthesis genes in Lactococcus lactis subsp. lactis. J Bacteriol. 1992;174(20):6563-70.

68. van Kranenburg R, Kleerebezem M, van Hylckama Vlieg JET, Ursing BM, Boekhorst J, Smit BA, et al. Flavour formation from amino acids by lactic acid bacteria: predictions from genome sequence analysis. Int Dairy J. 2002; 12:111-21.

69. Kleerebezem M, Boekhorst J, van Kranenburg R, Molenaar D, Kuipers OP, Leer $R$, et al. Complete genome sequence of Lactobacillus plantarum WCFS1. Proc Natl Acad Sci. 2003;100(4):1990-5.

70. Velly H, Renault P, Abraham AL, Loux V, Delacroix-Buchet A, Fonseca F, et al. Genome sequence of the lactic acid bacterium Lactococcus lactis subsp. lactis TOMSC161, isolated from a nonscalded curd pressed cheese. Genome Announc. 2014;2(6):e01121-14.

71. Odunfa SA, Adeniran SA, Teniola OD, Nordstrom J. Evaluation of lysine and methionine production in some Lactobacilli and yeasts from Ogi. Int J Food Microbiol. 2001;63(1):159-63.

72. Tarek ME, Hesham EM. Screening of potential infants' Lactobacilli isolates for amino acids production. Afr J Microbiol Res. 2010:4(4):226-32.

\section{Ready to submit your research? Choose BMC and benefit from:}

- fast, convenient online submission

- thorough peer review by experienced researchers in your field

- rapid publication on acceptance

- support for research data, including large and complex data types

- gold Open Access which fosters wider collaboration and increased citations

- maximum visibility for your research: over $100 \mathrm{M}$ website views per year

At BMC, research is always in progress.

Learn more biomedcentral.com/submissions 